International Journal of Current Microbiology and Applied Sciences

ISSN: 2319-7706 Volume 10 Number 11 (2021)

Journal homepage: http://www.ijcmas.com

\title{
Evaluation of Surface Water Contamination Using Heavy Metal Pollution Indices in the Mgoua Watershed, Southwestern Cameroon
}

\author{
Josephine Ndjama $^{1 *}$, GeorgeMafany ${ }^{1}$, Biram Eric Belmond ${ }^{1}$, \\ Yvette Clarisse Mfopou Mewouo ${ }^{2}$, Carine Tarkang ${ }^{1}$, Amina Aboubakar ${ }^{2}$, \\ Opportune Léonelle Apohkeng Dongmo ${ }^{1}$ and Armel Zacharie Ekoa Bessa ${ }^{3 *}$
}

\author{
${ }^{1}$ Hydrological Research Center (HRC), Institute of Geological and Mining Research (IRGM), \\ P.O. Box 4110 Nlongkak-Yaoundé, Cameroon \\ ${ }^{2}$ Laboratory of soil, plant, water and fertilizer, Institute of Agricultural Research for \\ Development (IRAD), P.O. Box 2123 Yaoundé, Cameroon \\ ${ }^{3}$ Department of Earth Sciences, University of Yaoundé 1, P.O. Box: 812,
}

Yaoundé I, Cameroon

*Corresponding author

\section{A B S T R A C T}

\section{Keywords}

Surface water, heavy metals, pollution indices, water quality, Mgoua watershed

Article Info

Received: 02 October 2021 Accepted: 07 November 2021 Available Online: 10 November 2021
An integrated pollution assessment index approach was used to assess the application of heavy metal pollution indices in the Ngoua watershed in southwestern (SW) Cameroon. The concentrations of $\mathrm{Pb}, \mathrm{Cr}, \mathrm{Cu}, \mathrm{Ni}, \mathrm{Zn}, \mathrm{Mo}, \mathrm{Fe}$ and $\mathrm{Al}$ in most of the water samples exceeded the maximum allowable concentration recommended by the World Health Organization (WHO). The Heavy Metal Evaluation Index (HEI) shows strong correlations with the Heavy Metal Pollution Index (HPI), Metal Index (MI) and the degree of contamination $\left(\mathrm{C}_{\mathrm{d}}\right)$, and gives a better assessment of the pollution levels. Selected samples from the 10 sampling stations were classified as high polluted in $C_{d}$, MI and HPI in relation to the respective critical values. These values show comparable results to those of the HEI and indicate that about $88 \%$ of the samples with above average values were classified as highly contaminated and the remaining samples $(12 \%)$ with below average values were classified as moderately contaminated. The Enrichment Factor (EF) analysis and the pollution indices reveal that the water quality is mainly controlled by natural and geogenic processes with major anthropogenic input. The current level of heavy metal distribution in the water of the Ngoua catchment is an environmental and health concern and requires special attention.

\section{Introduction}

The Mgoua river catchment, that harbours an active industrial area, is one of the principal catchments in south western Cameroon because its water is used for a wide range of purposes that include among many others, domestic, irrigation, fisheries, navigation, and industrial uses (Ndjama et al., 2008; Noa Tang et al., 2021). However, the quality of the 
water, that is very important for human health and for the environment, has been undermined by anthropogenic factors such as agriculture, urbanization, industrialization and rapid population growth. These activities are culminating in the indiscriminate discharge of warm waste/effluent water, laden with heavy metals into the surface waters of the catchment. This is similar to what has been observed elsewhere in the world where various kinds of pollutants, like heavy metals and inorganic ions have been introduced into surface waters through different mechanisms (Bhardwaj et al., 2017; Pandey and Singh, 2017; Ekoa Bessa et al., 2018a).

In spite of their contaminant potential, not all heavy metals are toxic. Antoine et al., (2012) and Myvizhi and Devi (2020), have categorized heavy metals into two main groups: one as biologically essential and the other as nonessential. Heavy metals such as cobalt $(\mathrm{Co})$, copper $(\mathrm{Cu})$, chromium $(\mathrm{Cr})$, iron $(\mathrm{Fe})$, manganese (Mn), molybdenum (Mo), nickel (Ni), vanadium (V) and zinc ( $\mathrm{Zn})$ are characterized as essential because they play an indispensable role in the functioning of living beings (animals and human). For example, they play a very important role in different metabolic functions and enzymatic activities and in protein transport. However, when their concentrations exceed a certain threshold, they become toxic (Jaishankar et al., 2014; Binam Mandeng et al., 2019; Armstrong-Atrin et al., 2021). On the other hand, non-essential heavy metals such as aluminum (Al), arsenic (As), barium $(\mathrm{Ba})$, cadmium $(\mathrm{Cd})$, lead $(\mathrm{Pb})$, strontium ( $\mathrm{Sr}$ ), titanium $(\mathrm{Ti})$, rubidium $(\mathrm{Rb})$, zirconium ( $\mathrm{Zr}$ ), lithium (Li), yttrium $(\mathrm{Y})$ and uranium (U) are toxic even at very low levels. Assessment of heavy metal contamination in basins and even rivers is therefore important due to the threat they may pose by way of their bio magnifications and their toxicity to aquatic life, human health and to the environment (Ahmed et al., 2015; Ali et al.,
2016; Ekoa Bessa et al., 2018b;EkoaBessa et al., 2021; Tchatchouang Chougong et al., 2021). Heavy metal indices have been computed to assess the suitability level of water resources for drinking and non-drinking and also determine how the quality of these waters impact on the environment (Ndam Ngoupayou et al., 2007; Noa Tang et al., 2021).

In the Mgoua catchment, prevailing factors such as increasing industrialization, spreading urbanization and increasing population without an accompanying adequate waste disposal scheme have increased the vulnerability of the surface water to contamination. This makes it imperative for the heavy metal load, a most likely contaminant, to be evaluated. This will help determine the potability of the water and its impact in the environment. In this study, an attempt has been made, for the first time, to determine the heavy metal content $(\mathrm{Pb}, \mathrm{Cr}$, $\mathrm{Cu}, \mathrm{Cd}, \mathrm{Co}, \mathrm{Ni}, \mathrm{As}, \mathrm{Zn}, \mathrm{U}, \mathrm{Mo}, \mathrm{Fe}, \mathrm{Al}, \mathrm{Mn}$, $\mathrm{Ba}, \mathrm{Ti}, \mathrm{Sr}, \mathrm{Rb}, \mathrm{Zr}, \mathrm{Y}, \mathrm{V}, \mathrm{Li}$,) of surface water in the catchment and then deploy different pollution indices (HPI, HEI, MI, $\mathrm{C}_{\mathrm{d}}$ and $\mathrm{EF}$ ) to establish the suitability of the water for drinking and other purposes. This has been done against a backdrop of the WHO standards.

\section{Materials and Methods}

\section{Study area}

The Mgoua watershed is one of the seven watersheds of the Douala sedimentary basin, extending between $4^{\circ} 00^{\prime}$ and $4^{\circ} 02^{\prime}$ of latitude North and between $9^{\circ} 42^{\prime}$ and $9^{\circ} 45^{\prime}$ of longitude East (Fig.1). This 780 ha catchment is the site of many industrial activities that range from soap manufacturing, through paint production to brewery. Its more or less flat topography with altitudes of no more than $100 \mathrm{~m}$, characteristic of coastal lowlands, leads 
to poor drainage of the wastewater which in turn promotes water pollution. The climate is typically equatorial, characterized by two seasons: a long rainy season of about 9 months (March to November) and a short dry season of about 3 months (December to February). Meteorological data from the locality's national archives show that the average annual rainfall in the study area is $4000 \mathrm{~mm} /$ year. The temperature varies from 23 to $30^{\circ} \mathrm{C}$, with an average value of $27^{\circ} \mathrm{C}$ (Belmonte, 1966). Winds are rarely violent, with an average speed of $1 \mathrm{~m} / \mathrm{s}$ and the maximum speed does not exceed $14 \mathrm{~m} / \mathrm{s}$ (Ketchemen, 2011).

Fig.1 Location of Ngoua basin and different sampling stations

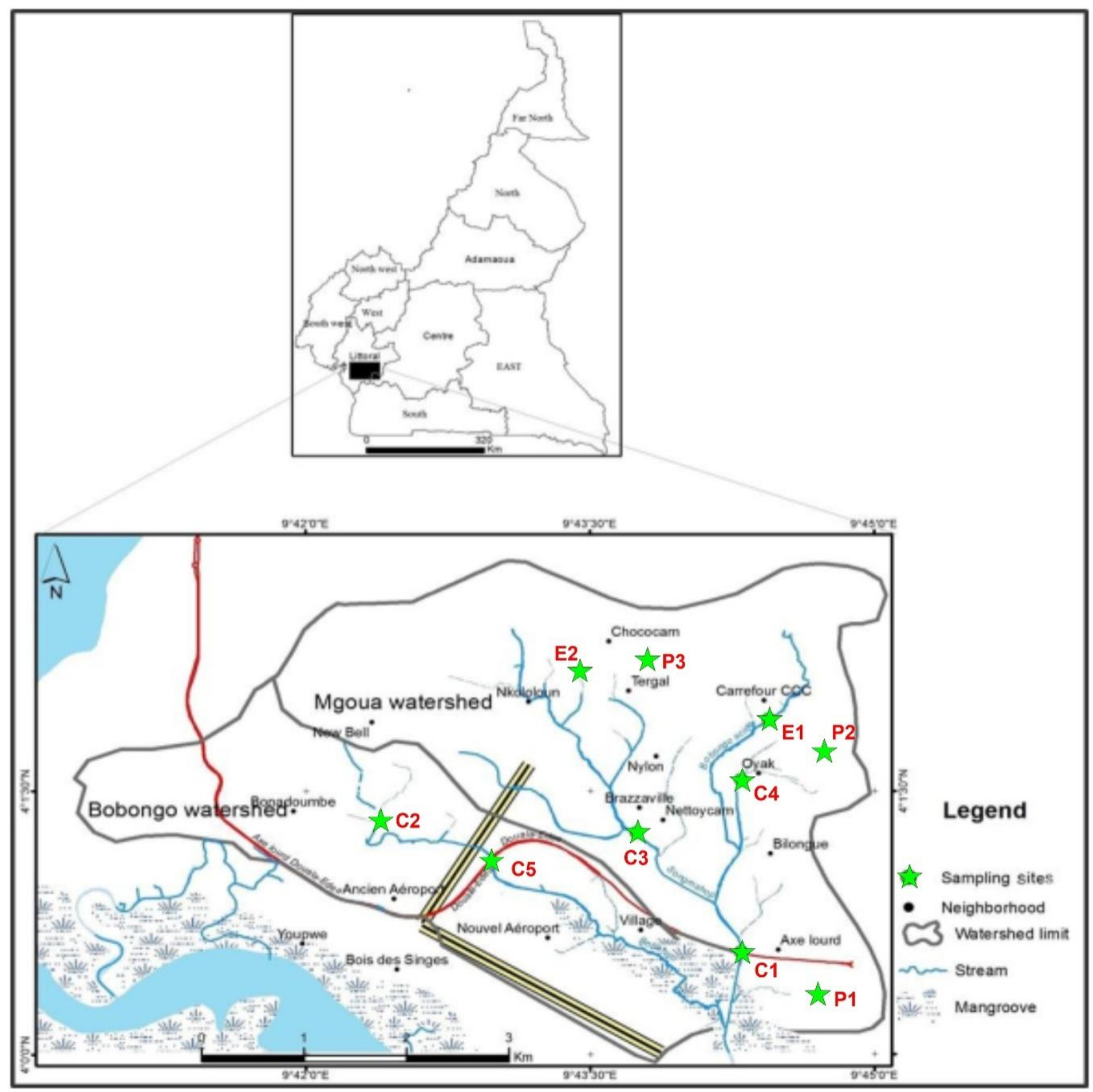


The lithology of the Douala sedimentary basin shows several formations grouped according to their ages of deposition: Quaternary, Tertiary and Secondary (Njike, 1984; Regnoult, 1986; and Ngueutchoua et al., 2019). The Wouri formation makes up the Quaternary sediments that are typified by limestones and clays such as kaolinite, smectite and illite. Tertiary sediments occur in Nkapa, Souellaba and Matanda formations. They of consists of black or brown clays with a few small sandy banks, clayey sands as well as fine sands and gravels alternating with plastic clays, arkosic sandstones showing layers of quartz with clay-limestone intercalations which become predominant towards the surface. The Logbaba and Mundeck formation make up the Secondary sediments. They consist of fossiliferous sandstone, sands and sandy clays (Dumort, 1968; Njike, 1984). The pedology of the study area is characterized by ferrallitic soils, hydromorphic soils, poorly evolved soils and rough mineral soils derived from sandstone and sandy-clay sediments (Ngueutchoua, 1996; Hieng, 2003).

\section{Sampling and sample analysis}

Sampling was done between March 2015 and February 2017. Ten samples were collected at different sites in the study area (Fig.1). Of the ten, five were from rivers ( $\mathrm{C} 1$ to $\mathrm{C} 5)$, three from shallow hand-dug wells (P1 to P3) and two (E1 and E2) from industrial effluents indiscriminately discharged from soap, brewery and paint producing plants into the riparian settlement.

All samples were filtered (Whatman no. $45 \mu \mathrm{m}$ ) and collected in $1000 \mathrm{ml}$ polyethylene bottles which were acidified with nitric acid $\left(\mathrm{HNO}_{3}\right)$ to a $\mathrm{pH}$ of 2 to prevent the precipitation of metal. They were all transferred to laboratory in iceboxes and refrigerated at $4{ }^{\circ} \mathrm{C}$ until the day of analysis (Edet et al., 2002). Samples were analyzed using Inductively Coupled Plasma Mass spectrometry (ICP-MS) with a Perkin-Elmer 5100 ZL equipment at the Geosciences and Environmental Laboratory at Toulouse (GET), in France.

\section{Evaluation methods}

Different methods were used for the evaluation pollution assessment in this study. They include Heavy Metal Pollution Index (HPI), Heavy metal Evaluation Index (HEI), Metal Index (MI), Degree of Contamination $\left(\mathrm{C}_{\mathrm{d}}\right)$ and Enrichment Factor $(\mathrm{EF})$.

These indices have been widely used to characterize the degree of pollution of each metal in the water (Brraich et al., 2015; Panigrahy et al., 2015; Tiwari et al., 2014; Ndjama et al., 2021). The methods are described below in detail.

\section{Heavy metal pollution index (HPI)}

HPI is a method that assesses the cumulative effects of individual heavy metals on the overall water quality (Mohan et al., 1996) and is calculated as shown:

$H P I=\frac{\sum_{i=1}^{\mathrm{M}} W i Q_{i}}{\sum_{i=1}^{\mathrm{I}} W i}$

where $\mathrm{W}_{\mathrm{i}}$ is the unit weighting of the $\mathrm{i}^{\text {th }}$ heavy metal, $Q_{i}$ is the sub-index for the $i^{\text {th }}$ heavy metal, and $\mathrm{n}$ is the number of heavy metals which equals $14(\mathrm{~Pb}, \mathrm{Cr}, \mathrm{Cu}, \mathrm{Cd}, \mathrm{Co}, \mathrm{Ni}, \mathrm{As}$, $\mathrm{Zn}, \mathrm{U}, \mathrm{Mo}, \mathrm{Fe}, \mathrm{Al}, \mathrm{Mn}$ and $\mathrm{Ba}$ ) for this study. The sub-index $\left(\mathrm{Q}_{\mathrm{i}}\right)$ is computed as:

$Q i=\sum_{i=1}^{n} \frac{\llbracket M_{i}-I_{i} \rrbracket}{S_{i}-I_{i}} \times 100$

where $\mathrm{Mi}(\mu \mathrm{g} / \mathrm{L})$ is the examined value of the $i^{\text {th }}$ heavy metal. Ii and $\mathrm{Si}$ are the ideal and standards values, respectively, for drinking water taken from WHO (2017) for the heavy metals $(\mu \mathrm{g} / \mathrm{L})$. A value of HPI below 100 
represents low pollution of heavy metals, while 100 is the threshold value at which harmful health consequences are probable. An HPI value greater than 100 indicates the water is unsuitable for consumption.

\section{Heavy metal evaluation index (HEI)}

The Heavy metal evaluation index (HEI) gives an overall quality of the water regarding heavy metal content. It is computed from the following equation (Edet and Offiong, 2002) as follows:

$H E I=\sum_{\mathrm{i}=1}^{\mathrm{n}} \frac{\mathrm{H}_{\mathrm{C}}}{\mathrm{H}_{\operatorname{mac}}}$

where, $\mathrm{H}_{\mathrm{c}}$ indicates monitored value of the $\mathrm{i}^{\text {th }}$ parameter and $\mathrm{H}_{\mathrm{mac}}$ indicates maximum admissible concentration (MAC) of the $i^{\text {th }}$ parameter (Sobhanardakani, 2016).

According to Edet and Offiong (2002), the water quality is classified into three categories as follows: $\mathrm{HEI}<10$ for low, $10<\mathrm{HEI}<20$ for moderate and HEI $>20$ is high pollution. This index was used for a better understanding of the pollution indices and was calculated for $\mathrm{Pb}, \mathrm{Cr}, \mathrm{Cu}, \mathrm{Cd}, \mathrm{Co}, \mathrm{Ni}, \mathrm{As}, \mathrm{Zn}, \mathrm{U}, \mathrm{Mo}, \mathrm{Fe}, \mathrm{Al}$, $\mathrm{Mn}$ and $\mathrm{Ba}$ among the selected trace metals.

\section{Metal Index (MI)}

The metal index (MI) is another index generally used for estimating the quality of water for different utilizations (Tamasi et al., 2004). This assessment method addresses the effects of heavy metals on human health and helps to quickly appraise the overall quality of drinking waters (Mambenga et al., 2017). Metal index is determined by the equation of Tamasi et al., (2004):

$M I=\sum_{i=1}^{n} \frac{C_{i}}{(M A C)_{i}}$ where $(\mathrm{MAC})_{\mathrm{i}}$ is maximum allowable concentration for $\mathrm{i}$ and $\mathrm{C}_{\mathrm{i}}$ is the mean concentration of each metal element. MI values greater than 1 is a threshold of warning (Addey et al., 2018, Zahra Khoshnam et al., 2017). Boateng et al., (2019) have used MI values to establish six classes of water quality: very pure $(<0.3)$, pure $(0.3-1.0)$, slightly affected $(1.0-2.0)$, moderately affected $(20-$ $4.0)$, strongly affected $(4.0-6.0)$ and seriously affected.

\section{Degree of Contamination $\left(\mathbf{C}_{\mathrm{d}}\right)$}

The $C_{d}$ method gives an estimate of the quality of water with respect to the degree of contamination using contamination factor. Therefore, the $C_{d}$ recapitulates the combined effects of a number of quality parameters regarded as unsafe to domestic water (Nasrabadi, 2015).

$\mathrm{C}_{\mathrm{d}}$ also known as contamination index, was developed by Backman et al., (1997) and is also used as reference for estimating the extent for metal pollution (Rubio et al., 2000). Degree of contamination is a sum of the contamination factors of the individual parameters that exceed the upper respective permissible values and is calculated as follows:

$\mathrm{C}_{\mathrm{d}}=\sum_{i=0}^{n} C f_{i}^{i}$

$\mathrm{C}_{\mathrm{fi}}=\frac{C_{\mathrm{i}}}{C_{n}}-1$

where, $\mathrm{C}_{\mathrm{fi}}$ is contamination factor for a single component, $\mathrm{C}_{\mathrm{i}}$ is analytical value for the component and $\mathrm{C}_{\mathrm{n}}$ is upper permissible concentration of the component. $\mathrm{C}_{\mathrm{d}}$ has been used in previous research to assess the degree of metal pollution. It was calculated for $\mathrm{Pb}$, $\mathrm{Cr}, \mathrm{Cu}, \mathrm{Cd}, \mathrm{Co}, \mathrm{Ni}$, As, Zn, U, Mo, Fe, Al, Mn and $\mathrm{Ba}$ among the selected trace metals. 
According to Nasrabadi (2015), $\mathrm{C}_{\mathrm{d}}$ values are regrouped into three categories as follows: $\mathrm{C}_{\mathrm{d}}<1 \quad$ (low), $\mathrm{C}_{\mathrm{d}}=1-3$ (medium) and $\mathrm{C}_{\mathrm{d}}>3$ (high).

\section{Enrichment Factor (EF)}

Enrichment factor (EF) is commonly used to determine whether the sources of the metals are geogenic and/or anthropogenic as well as to assess the degree of metal contamination (Surindra et al., 2019; Olivares-Rieumont et al., 2005). EF values lower than 1.5 indicate geogenic sources (natural source), while those greater than 1.5 indicate anthropogenic sources (Wang et al., 2008). Andrews and Sutherland (2004) suggested five contamination categories of enrichment factor and they are presented in Table 1.

Table.1 Enrichment factor according to Andrews and Sutherland (2004)

\begin{tabular}{|c|c|}
\hline EF Value & Quality \\
\hline $\mathbf{2}$ & Minimal enrichment \\
\hline $\mathbf{2 - 5}$ & Moderate enrichment \\
\hline $\mathbf{5 - 2 0}$ & Significant enrichment \\
\hline $\mathbf{2 0 - 4 0}$ & Very highly enriched \\
\hline $\mathbf{> 4 0}$ & Extremely highly enriched \\
\hline
\end{tabular}

Originally proposed by Buat-Menard and Chesselet (1979) to assess the metal enrichment in the water, it is expressed as:

$\mathrm{EF}=\left[\left({ }^{\left.M_{n} / M_{r e f}\right) \text { sample }}\right] /\left({ }^{B_{n} / B_{r e f}}\right)\right.$

where $M_{m \text { (sample) }}$ is the content of the examined element, ${ }^{M_{\text {ref(sample) }} \text { is the content }}$ of the reference element, ${ }^{B_{n}}$ is the background value of the reference element. For this study, Fe was used as the reference at the average trace element content of rivers worldwide value (Gaillardet et al., 1999).

\section{Results and Discussion}

\section{Heavy metal concentrations}

The statistics of the concentration of twentyone heavy metals analyzed for the ten water samples, WHO (2017) guidelines and the average trace element content of rivers worldwide (Gaillardet et al., 1999) is provided in Table 2. The average concentration values of all heavy metals in the water samples of this study range from 0.07 to $8151.60 \mu \mathrm{g} / \mathrm{l}$ with an average of $788.41 \mu \mathrm{g} / \mathrm{l}$. Among all the analyzed heavy metals, the highest mean values detected are for $\mathrm{Fe}(8151.60 \mu \mathrm{g} / \mathrm{l})$ followed by $\mathrm{Ni}(4355.84 \mu \mathrm{g} / \mathrm{l})$ and $\mathrm{Cr}$ (3089.03 $\mu \mathrm{g} / \mathrm{l})$, while the lowest average concentration is observed for $\mathrm{U}(0.07 \mu \mathrm{g} / \mathrm{l})$ followed by $\mathrm{Cd}(0.12 \mu \mathrm{g} / \mathrm{l}), \mathrm{Mn}(0.42 \mu \mathrm{g} / \mathrm{l})$ and $\mathrm{Zr}(0.48 \mu \mathrm{g} / \mathrm{l})$. Based on the mean concentration level and value for the twentyone heavy metals analyzed in the stream water of the Mgoua catchment, the heavy metals are relatively ranked from the smallest to the highest value as follows: $\mathrm{U}<\mathrm{Cd}<\mathrm{Mn}<\mathrm{Zr}<$ As $<\mathrm{Y}<\mathrm{V}<\mathrm{Pb}<\mathrm{Rb}<\mathrm{Li}<\mathrm{Mo}<\mathrm{Ba}<\mathrm{Co}<$ $\mathrm{Cu}<\mathrm{Ti}<\mathrm{Sr}<\mathrm{Al}<\mathrm{Zn}<\mathrm{Cr}<\mathrm{Ni}<\mathrm{Fe}$.

A comparison of the mean concentration values of heavy metals in the study area with WHO standard values, shows that more than $50 \%$ of the heavy metals $(\mathrm{Pb}, \mathrm{Cr}, \mathrm{Cu}, \mathrm{Ni}, \mathrm{Zn}$, $\mathrm{Mo}, \mathrm{Fe}$ and $\mathrm{Al}$ ) are above the permissible standard values of WHO (2017) while the rest (Cd, As, U, Mo, Mn, Ba and V)fall below (Table 2). But for $\mathrm{U}, \mathrm{Mn}$ and $\mathrm{Ti}$, all selected heavy metals in the Mgoua catchment are higher than the allowable limit for the Worldwide River average set by Gaillard et al., (1999). From the foregoing, $\mathrm{Cd}, \mathrm{Cr}, \mathrm{Cu}$, $\mathrm{Ni}, \mathrm{Zn}$ and $\mathrm{Al}$ are the heavy metals from the samples in the study area that have the potential to deteriorate human health because their values are higher than WHO (2017) standards and Worldwide River average (Gaillard et al., 1999). This corroborates 
Domingo (1994) and Goorzadi et al., (2009) assertion that although some elements are essential for humans, they can be dangerous at relatively high exposure levels.

\section{Pollution evaluation indices}

Five main tools were used to assess the risk level of metal contamination in the samples, notably HPI, MI, HEI, $\mathrm{C}_{\mathrm{d}}$ and $\mathrm{EF}$.

The HPI of the Mgoua surface waters ranges from 55.57 (E2) to 17468.08 (P1) with a mean of 1990.64 (Table 3 ). Their pollution status is illustrated in Figure.2 that shows that the concentration of all but one of the samples (E2) exceeds the threshold value of the pollution index which is 100 . These values are higher than those reported by Dolma et al., (2015) in the Sirsa Bassin in India (HPI 16.78), while they are lower than those obtained by Enaam and Abdullah (2013) in Delta River (HPI 2097). Measured against the work of Prasad and Bose (2001), the Mgoua values indicate that there is heavy metal pollution of the surface waters in the area and the source could be attributed mainly to domestic sewage and industrial discharge.

Table 4 shows that MI varies from 14.70 to 2977.38 with a mean value of 337.20 . The highest value is observed in site P1 (2977.38) and the lowest value in site E2 (14.70) with the rest falling within that bracket in the following increasing sequence: $\mathrm{E} 2<\mathrm{P} 3<\mathrm{C} 5<$ $\mathrm{C} 1<\mathrm{P} 2<\mathrm{E} 1<\mathrm{C} 3<\mathrm{C} 2<\mathrm{C} 4<\mathrm{P} 1$. Against a backdrop of the work of Boateng et al., (2019), the Mgoua waters are seriously polluted with $\mathrm{Pb}, \mathrm{Cr}$, $\mathrm{Ni}$ and $\mathrm{Fe}$, moderately polluted with Mo and slightly polluted with Al. This is due to the big number of industries including thermal power plant, fertilizer, chemical and mineral processing plants, textile mills, match factories and nearly 200 small scale industries that are located the area.

The HEI values range from 14.702 to 2977.39 with an average of 337.201 (Table 5). The highest value is observed in site P1 (2977.39) and the lowest in site E2 (14.702). The order for mean values of HEI is as follows: $\mathrm{E} 2<\mathrm{P} 3$ $<$ C5 $<$ C1 $<$ P2 $<$ E1 $<$ C3 $<$ C2 $<$ C4 $<$ P 1 . According to the classification proposed by Edet and Offiong (2002), sampling sites C1, $\mathrm{C} 5, \mathrm{P} 2, \mathrm{P} 3$ and E2 have low pollution (HEI $<$ 27), sites $\mathrm{C} 2, \mathrm{C} 3$ and $\mathrm{E} 1$ have medium pollution $(27<\mathrm{HEI}<54)$, while sites $\mathrm{C} 4$ and P1 have high pollution (HEI $>54$ ). This observation can be explained by the downstream position of $\mathrm{C} 4$ and $\mathrm{P} 1$ which favors the accumulation of heavy metal. Similar observations have been made in the waters of Nile Delta in Egypt (Hegazy et al., 2020).

The $\mathrm{C}_{\mathrm{d}}$ of the studied water ranges from 34.27 (E2) to 13783.91 (P1), with a mean value of 1557.36 (Table 6). These values exceed 36 in 9of the 10samples with only 1 (sample E2 with value of 37.27) falling in the medium zone $\left(18<\mathrm{C}_{\mathrm{d}}<36\right)$ of pollution. They are far above those obtained by Dolma et al., (2015) and underscore water of very poor drinking quality.

\section{Enrichment Factor of the heavy metals}

The values obtained in this study are presented in Table 7. They vary from 0.00092 for $\mathrm{Mn}$ to 491.24 for $\mathrm{Ni}$, with an average of 26.88. EF values from Mgoua watershed follow the descending other of $\mathrm{Ni}>\mathrm{Y}>\mathrm{Cr}>\mathrm{Cu}>\mathrm{Zn}>\mathrm{Pb}>$ $\mathrm{Rb}>\mathrm{Fe}>\mathrm{Mo}>\mathrm{Li}>\mathrm{Ti}>\mathrm{V}>\mathrm{Sr}>\mathrm{Co}>\mathrm{Zr}>\mathrm{Al}>\mathrm{Ba}>\mathrm{As}$ $>\mathrm{U}>\mathrm{Cd}>\mathrm{Mn}$. 
Table.2 Evaluation of heavy metals concentration of waters in Mgoua catchment and comparison with guidelines $(\mu \mathrm{g} / \mathrm{L})$

\begin{tabular}{|c|c|c|c|c|c|}
\hline Heavy metal & Min. & Max. & Avg. & World Rivers avg. & WHO 2017( $\boldsymbol{\mu g} / \mathbf{l})$ \\
\hline $\mathbf{P b}$ & 0.003 & 156.13 & 18.83 & 0.08 & 10 \\
\hline $\mathbf{C r}$ & 12.15 & 29092.38 & 3089.03 & 0.7 & 50 \\
\hline $\mathbf{C u}$ & 4.3 & 283.57 & 40.1 & 0.15 & 10 \\
\hline $\mathbf{C d}$ & 0.01 & 0.79 & 0.12 & 0.8 & 20 \\
\hline $\mathbf{C o}$ & 1.78 & 314.38 & 37.04 & 1.48 & 2000 \\
\hline $\mathbf{N i}$ & 118.47 & 38190.07 & 4355.84 & 0.08 & 10 \\
\hline $\mathbf{A s}$ & 0.22 & 4.07 & 1.02 & 0.62 & 10 \\
\hline $\mathbf{Z n}$ & 21.21 & 2235.15 & 275.9 & 0.6 & 50 \\
\hline $\mathbf{U}$ & 0.01 & 0.23 & 0.07 & 0.37 & 30 \\
\hline $\mathbf{M o}$ & 1.91 & 239.15 & 28.85 & 0.42 & 70 \\
\hline $\mathbf{F e}$ & 352.35 & 69681.95 & 8151.6 & 66 & 3 \\
\hline $\mathbf{A l}$ & 11.68 & 1638.77 & 237.8 & 32 & 200 \\
\hline $\mathbf{M n}$ & 0.04 & 1.4 & 0.42 & 34 & 200 \\
\hline $\mathbf{B a}$ & 12.69 & 46.58 & 30.18 & 23 & 300 \\
\hline $\mathbf{T i}$ & 0.66 & 592.19 & 64.68 & 0.489 & - \\
\hline $\mathbf{S r}$ & 4.55 & 510.24 & 162.91 & 60 & - \\
\hline $\mathbf{V}$ & 0.3 & 94.84 & 11.64 & 0.71 & 50 \\
\hline $\mathbf{L i}$ & 2.02 & 197.75 & 27.85 & 1.84 & - \\
\hline $\mathbf{R b}$ & 7.88 & 39.44 & 19.3 & 1.63 & - \\
\hline $\mathbf{Y}$ & 0.02 & 26.87 & 2.95 & 0.04 & - \\
\hline $\mathbf{Z r}$ & 0.02 & 3.84 & 0.48 & 0.039 & - \\
\hline
\end{tabular}

Table.3 HPI recorded at the different sampling stations

\begin{tabular}{|c|c|c|c|c|c|c|c|c|c|c|}
\hline Station & C1 & C2 & C3 & C4 & C5 & P1 & P2 & P3 & E1 & E2 \\
\hline HPI & 161.02 & 355.51 & 233.47 & 958.59 & 199.32 & 17468.08 & 186.87 & 168.40 & 119.60 & 55.57 \\
\hline Average & & \multicolumn{7}{|c|}{1990.64} \\
\hline
\end{tabular}


Table.4 Metal Index (MI) of studied samples of Mgoua watershed

\begin{tabular}{|c|c|c|c|c|c|c|c|}
\hline Heavy metal & $\mathbf{S i}$ & $\mathbf{W i}$ & $\mathbf{I}$ & $\mathbf{M A C}$ & Sample & MI & Class \\
\hline $\mathbf{P b}$ & 100 & 0.01 & 10 & 1.5 & $\mathrm{C} 1$ & 23.53 & VI \\
\hline $\mathbf{C r}$ & 50 & 0.02 & 50 & 50 & $\mathrm{C} 2$ & 50.07 & VI \\
\hline $\mathbf{C u}$ & 1000 & 0.001 & 2000 & 1000 & $\mathrm{C} 3$ & 41.01 & VI \\
\hline $\mathbf{C d}$ & 3 & 0.33 & 3 & 3 & $\mathrm{C} 4$ & 164.09 & VI \\
\hline $\mathbf{C o}$ & 10 & 0.1 & - & 1000 & $\mathrm{C} 5$ & 23.49 & VI \\
\hline $\mathbf{N i}$ & 20 & 0.05 & 20 & 20 & $\mathrm{P} 1$ & 2977.39 & VI \\
\hline $\mathbf{A s}$ & 50 & 0.02 & 10 & 50 & $\mathrm{P} 2$ & 25.00 & VI \\
\hline $\mathbf{Z n}$ & 5000 & 0.0002 & 5000 & 5000 & $\mathrm{P} 3$ & 22.72 & VI \\
\hline $\mathbf{U}$ & 30 & 0.033 & - & 3 & $\mathrm{E} 1$ & 30.01 & VI \\
\hline $\mathbf{M o}$ & 70 & 0.014 & - & 10 & $\mathrm{E} 2$ & 14.70 & VI \\
\hline $\mathbf{F e}$ & 300 & 0.0033 & 200 & 200 & Mean & 337.20 & - \\
\hline $\mathbf{A l}$ & 200 & 0.005 & - & 200 & & & \\
\hline $\mathbf{M n}$ & 300 & 0.0033 & 50 & 50 & & & \\
\hline $\mathbf{B a}$ & 300 & 0.0033 & - & 1300 & & & \\
\hline
\end{tabular}

Table.5 HEI recorded at different sampling stations

\begin{tabular}{|c|c|c|c|c|c|c|c|c|c|c|}
\hline Station & C1 & C2 & C3 & C4 & C5 & P1 & P2 & P3 & E1 & E2 \\
\hline HPI & 23.527 & 50.066 & 41.008 & 164.086 & 23.491 & 2977.391 & 25.004 & 22.724 & 30.012 & 14.702 \\
\hline Average & & \multicolumn{7}{|c|}{337.201} \\
\hline
\end{tabular}

Table.6 Recorded values of contaminant index $\left(\mathrm{C}_{\mathrm{d}}\right)$

\begin{tabular}{|c|c|c|c|c|c|c|c|c|c|c|}
\hline Heavy metal & $\mathbf{C 1}$ & $\mathbf{C 2}$ & $\mathbf{C 3}$ & $\mathbf{C 4}$ & $\mathbf{C 5}$ & $\mathbf{P 1}$ & $\mathbf{P 2}$ & $\mathbf{P 3}$ & $\mathbf{E 1}$ & $\mathbf{E 2}$ \\
\hline $\mathbf{P b}$ & -0.54 & -1 & 0.15 & 5.6 & -0.63 & 103.09 & -0.77 & -0.68 & 9.87 & 0.42 \\
\hline $\mathbf{C r}$ & -0.24 & 0.8 & 2.72 & 25.34 & -0.02 & 580.85 & -0.22 & -0.4 & -0.25 & -0.76 \\
\hline $\mathbf{C u}$ & -0.99 & -0.98 & -0.99 & -0.98 & -0.99 & -0.72 & -0.99 & -0.99 & -0.98 & -1 \\
\hline $\mathbf{C d}$ & -1 & -0.99 & -0.99 & -0.97 & -0.99 & -0.74 & -1 & -0.98 & -0.97 & -0.99 \\
\hline $\mathbf{C o}$ & -1 & -0.99 & -0.99 & -0.98 & -0.99 & -0.69 & -1 & -1 & -1 & -1 \\
\hline $\mathbf{N i}$ & 107.68 & 278.23 & 170.3 & 701.85 & 129.91 & 12729.02 & 139.25 & 125.16 & 89.57 & 38.49 \\
\hline $\mathbf{A s}$ & -0.98 & -0.99 & -0.98 & -0.98 & -0.99 & -0.92 & -0.99 & -0.99 & -0.98 & -1 \\
\hline $\mathbf{Z n}$ & -1 & -0.99 & -0.99 & -0.96 & -0.99 & -0.55 & -0.99 & -0.99 & -0.99 & -0.98 \\
\hline $\mathbf{U}$ & -0.98 & -0.99 & -0.98 & -0.98 & -0.98 & -0.98 & -0.92 & -0.98 & -0.98 & -1 \\
\hline $\mathbf{M o}$ & -0.67 & -0.04 & -0.45 & 0.33 & -0.53 & 22.91 & -0.63 & -0.58 & -0.68 & -0.81 \\
\hline $\mathbf{F e}$ & 4.5 & 4.08 & 8.71 & 22.89 & 0.76 & 347.41 & 1.23 & 1.22 & 1.36 & 5.42 \\
\hline $\mathbf{A l}$ & -0.94 & -0.75 & -0.92 & -0.68 & -0.81 & 7.19 & -0.78 & -0.86 & 1 & -0.56 \\
\hline $\mathbf{M n}$ & -0.98 & -1 & -0.99 & -1 & -0.99 & -1 & -1 & -1 & -0.99 & -0.97 \\
\hline $\mathbf{B a}$ & -0.97 & -0.98 & -0.97 & -0.97 & -0.97 & -0.98 & -0.96 & -0.98 & -0.99 & -0.99 \\
\hline $\mathbf{C d}$ & 101.91 & 273.41 & 172.61 & 747.51 & 120.76 & 13783.91 & 130.21 & 115.96 & 93 & 34.27 \\
\hline Mean & & & & & 1557.36 & & & & \\
\hline
\end{tabular}


Table.7 Enrichment factor in water of the Ngoua watershed

\begin{tabular}{|c|c|c|c|c|c|c|c|c|c|c|c|c|c|}
\hline Heavy metal & $\mathbf{C 1}$ & $\mathbf{C 2}$ & $\mathbf{C 3}$ & $\mathbf{C 4}$ & $\mathbf{C 5}$ & $\mathbf{P 1}$ & $\mathbf{P 2}$ & $\mathbf{P 3}$ & $\mathbf{E 1}$ & $\mathbf{E 2}$ & Min. & Max. & Mean \\
\hline $\mathbf{P b}$ & 0.51 & 0 & 0.73 & 1.71 & 1.3 & 1.85 & 0.63 & 0.9 & 28.52 & 1.37 & 0 & 28.52 & 3.75 \\
\hline $\mathbf{C r}$ & 3.24 & 8.34 & 9.02 & 25.98 & 13.05 & 39.36 & 8.27 & 6.36 & 7.5 & 0.89 & 0.89 & 39.36 & 12.2 \\
\hline $\mathbf{C u}$ & 4.47 & 8.35 & 2.43 & 2.18 & 12.88 & 1.79 & 10.58 & 6.91 & 18.92 & 1.48 & 1.48 & 18.92 & 7 \\
\hline $\mathbf{C d}$ & 0 & 0 & 0 & 0 & 0 & 0 & 0 & 0.01 & 0.02 & 0 & 0 & 0.02 & 0 \\
\hline $\mathbf{C o}$ & 0.2 & 0.39 & 0.12 & 0.18 & 0.71 & 0.2 & 0.36 & 0.39 & 0.33 & 0.06 & 0.06 & 0.71 & 0.29 \\
\hline $\mathbf{N i}$ & 244.35 & 680.69 & 218.28 & 364.02 & 919.54 & 452.15 & 779.35 & 702.55 & 475.25 & 76.18 & 76.18 & 919.54 & 491.24 \\
\hline $\mathbf{A s}$ & 0.09 & 0.06 & 0.05 & 0.02 & 0.15 & 0.01 & 0.08 & 0.17 & 0.25 & 0.02 & 0.01 & 0.25 & 0.09 \\
\hline $\mathbf{Z n}$ & 2.12 & 6.32 & 2.31 & 4.21 & 9.08 & 3.53 & 12.75 & 7.26 & 7.79 & 6.62 & 2.12 & 12.75 & 6.2 \\
\hline $\mathbf{U}$ & 0.01 & 0 & 0.01 & 0 & 0.03 & 0 & 0.09 & 0.03 & 0.02 & 0 & 0 & 0.09 & 0.02 \\
\hline $\mathbf{M o}$ & 0.47 & 1.49 & 0.45 & 0.44 & 2.08 & 0.54 & 1.29 & 1.49 & 1.06 & 0.23 & 0.23 & 2.08 & 0.95 \\
\hline $\mathbf{A l}$ & 0.02 & 0.1 & 0.02 & 0.03 & 0.22 & 0.05 & 0.2 & 0.13 & 1.75 & 0.14 & 0.02 & 1.75 & 0.27 \\
\hline $\mathbf{M n}$ & 0 & 0 & 0 & 0 & 0 & 0 & 0 & 0 & 0 & 0 & 0 & 0 & 0 \\
\hline $\mathbf{B a}$ & 0.11 & 0.08 & 0.05 & 0.02 & 0.31 & 0 & 0.3 & 0.14 & 0.1 & 0.03 & 0 & 0.31 & 0.11 \\
\hline $\mathbf{T i}$ & 0.14 & 0.09 & 0.35 & 1.2 & 0.43 & 1.15 & 0.22 & 0.28 & 0.49 & 0.08 & 0.08 & 1.2 & 0.44 \\
\hline $\mathbf{S r}$ & 0.33 & 0.07 & 0.07 & 0.03 & 1.59 & 0 & 0.48 & 0.36 & 0.01 & 0.03 & 0 & 1.59 & 0.3 \\
\hline $\mathbf{V}$ & 0.04 & 0.07 & 0.05 & 0.11 & 0.17 & 0.13 & 0.06 & 0.96 & 1.43 & 0.05 & 0.04 & 1.43 & 0.31 \\
\hline $\mathbf{L i}$ & 0.58 & 0.07 & 0.04 & 0.04 & 2.51 & 0.1 & 0.34 & 0.17 & 1.53 & 0.06 & 0.04 & 2.51 & 0.55 \\
\hline $\mathbf{R b}$ & 0.92 & 0.47 & 0.66 & 0.23 & 2.02 & 0.01 & 1.07 & 3.59 & 0.68 & 0.38 & 0.01 & 3.59 & 1 \\
\hline $\mathbf{Y}$ & 0.03 & 0.06 & 0.02 & 0.02 & 125.82 & 0.05 & 0.65 & 0.25 & 0.51 & 0.15 & 0.02 & 125.82 & 12.75 \\
\hline $\mathbf{Z r}$ & 0.07 & 0.03 & 0.04 & 0.06 & 0.25 & 0.09 & 0.68 & 1.05 & 0.46 & 0.05 & 0.03 & 1.05 & 0.28 \\
\hline $\mathbf{M i n}$ & 0 & 0 & 0 & 0 & 0 & 0 & 0 & 0 & 0 & 0 & & \\
\hline $\mathbf{M a x}$. & 244.35 & 680.69 & 218.28 & 364.02 & 919.54 & 452.15 & 779.35 & 702.55 & 475.25 & 76.18 & & \\
\hline Mean & 12.89 & 35.33 & 11.74 & 20.02 & 54.61 & 25.05 & 40.87 & 36.65 & 27.33 & 4.39 & & \\
\hline & & & & & & & & & & & \\
\hline
\end{tabular}

Table.8 Classification of water quality based on modified categories of HPI, $\mathrm{C}_{\mathrm{d}}$ and HEI

\begin{tabular}{|c|c|c|c|c|c|}
\hline $\begin{array}{c}\text { Index } \\
\text { method }\end{array}$ & Class & $\begin{array}{c}\text { Extent of } \\
\text { pollution }\end{array}$ & $\begin{array}{c}\text { No of } \\
\text { samples }\end{array}$ & Percentage & Samples \\
\hline \multirow{2}{*}{ HPI } & $<15$ & Low & 0 & 0 & - \\
\cline { 2 - 6 } & $15-30$ & Medium & 0 & 0 & - \\
\hline \multirow{2}{*}{ Cd } & $>30$ & High & 10 & 100 & C1, C2, C3, C4, C5, P1, P2, P3, E1 and E2 \\
\cline { 2 - 6 } & $<18$ & Low & 0 & 0 & - \\
\cline { 2 - 6 } & $18-36$ & Medium & 1 & 10 & E2 \\
\cline { 2 - 6 } & $>36$ & High & 9 & 90 & $\mathrm{C} 1, \mathrm{C} 2, \mathrm{C} 3, \mathrm{C} 4, \mathrm{C} 5, \mathrm{P} 1, \mathrm{P} 2, \mathrm{P} 3, \mathrm{E} 1$ and E2 \\
\hline \multirow{2}{*}{ HEI } & $<27$ & Low & 5 & 50 & $\mathrm{C} 1, \mathrm{C}, \mathrm{P} 2, \mathrm{P} 3$ and E2 \\
\cline { 2 - 6 } & $27-54$ & Medium & 3 & 30 & $\mathrm{C} 2, \mathrm{C} 3$ and E1 \\
\cline { 2 - 6 } & $>54$ & High & 2 & 20 & $\mathrm{C} 4$ and P1 \\
\hline
\end{tabular}


Fig.2 HPI representation at different samplings stations

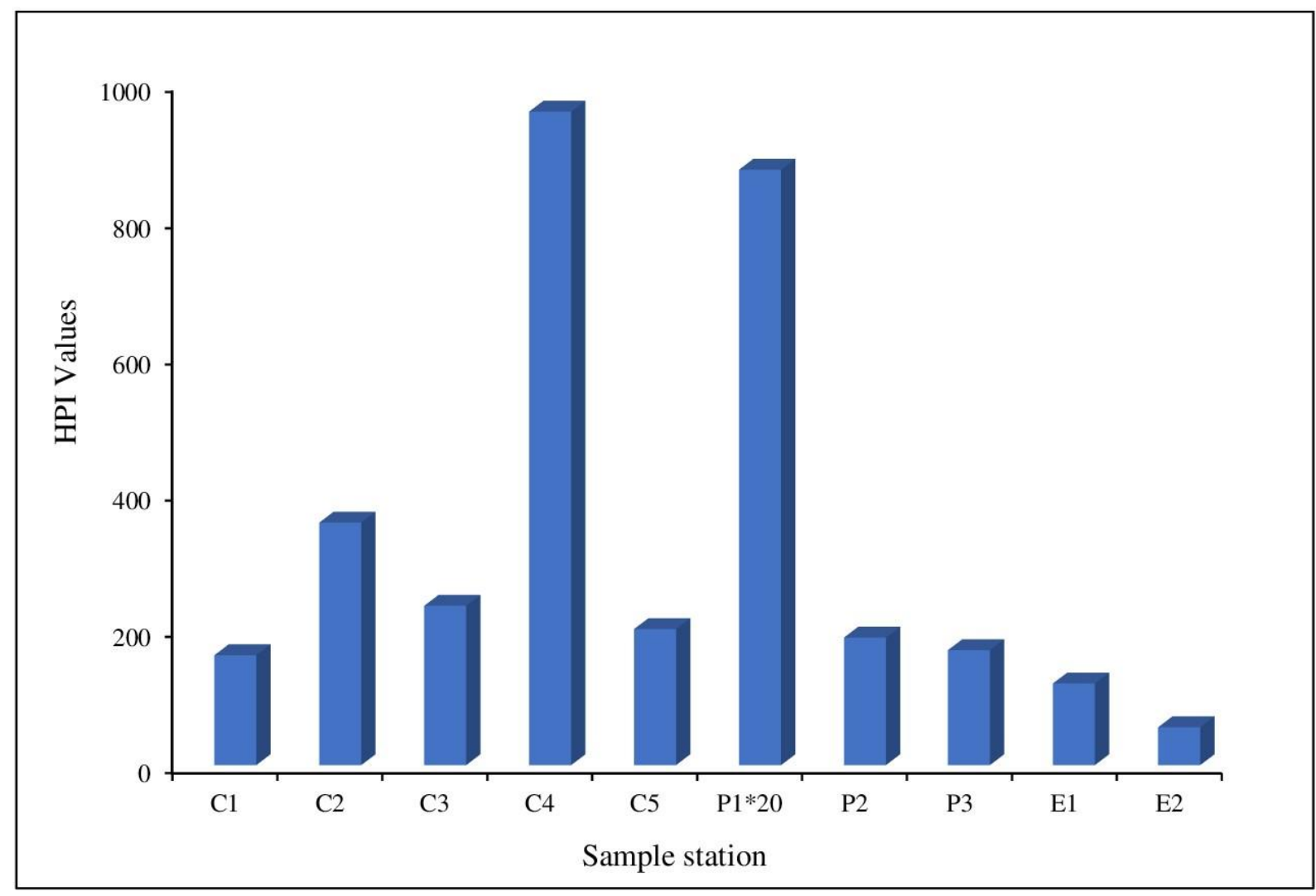

According to the classification proposed by Andrews and Sutherland (2004), stations C1, C2, C3, C4, P1, P2, P3 and E2 are minimally enriched $(\mathrm{EF}<2)$ with elements such as $\mathrm{Pb}$, Cd, Co, As, U, Mo, Al, Mn, Ba, Ti, Sr, V, Li, $\mathrm{Rb}, \mathrm{Y}$ and $\mathrm{Zr}$. Moderate enrichment $(2<\mathrm{EF}$ $<5$ ) is observed for $\mathrm{Cu}, \mathrm{Cr}$ and $\mathrm{Zn}$ instation $\mathrm{C} 2, \mathrm{Cu}$ and $\mathrm{Zn}$ in stations $\mathrm{C} 3$ and $\mathrm{P} 4$ respectively, $\mathrm{Mo}, \mathrm{Li}$ and $\mathrm{Rb}$ instation $\mathrm{C} 5, \mathrm{Zn}$ instation $\mathrm{P} 1$ and $\mathrm{Rb}$ instation $\mathrm{P} 2$. A very high enrichment is seen at stations $\mathrm{C} 4$ and $\mathrm{P} 1$ in $\mathrm{Cr}$ and station $\mathrm{E} 1 \mathrm{in} \mathrm{Pb}$. A significant enrichment $(5<\mathrm{EF}<20)$ is obtained at stationsC2 and $\mathrm{E} 1$ in $\mathrm{Cr}, \mathrm{Cu}$ and $\mathrm{Zn}$, station $\mathrm{C} 3$ in $\mathrm{Cr}$, at station $\mathrm{C} 5$ in $\mathrm{Zn}$, station $\mathrm{P} 2$ in $\mathrm{Cr}, \mathrm{Cu}$ and $\mathrm{Zn}$; at station $\mathrm{P} 3$ in $\mathrm{Cr}$ and $\mathrm{Cu}$ and station $\mathrm{E} 1$ in $\mathrm{Cr}$ and $\mathrm{Zn}$. The last category (extremely highly enriched; $\mathrm{EF}>40$ ) is represented by $\mathrm{Ni}$ at all sampling stations and $\mathrm{Y}$ in station $\mathrm{C} 5$. According to Wang et al., (2008), $\mathrm{Pb}, \mathrm{Cr}, \mathrm{Cu}$, $\mathrm{Ni}, \mathrm{Zn}$ and $\mathrm{Y}$ have EF > 1.5 signify that the sources of contamination are due by anthropogenic activities, while the lower values for the other heavy metals appoint to a geogenic origin (a natural source).

\section{Evaluation of water quality}

Pollution evaluation indices (HPI, HEI and $\mathrm{C}_{\mathrm{d}}$ ) were made individually using the international recommendations and are indicated in Table 8. The HPI assessment method shows that all sample sites are heavily polluted. The pollution level drops with the $\mathrm{Cd}$ method that shows that $90 \%$ of samplings sites are high polluted. The drop is even greater with the HEI method which reveals that only $20 \%$ of samples sites high polluted while $30 \%$ and 50\% show medium polluted and low polluted respectively. The high mean values of HPI, HEI and $\mathrm{C}_{\mathrm{d}}$ for all the sampling sites indicate hence polltuion. These averages show 
very alarming pollution compared to those obtained by Dolma et al., (2015) with low polluted samples, although the contexts are not very similar.

Heavy metals pollution evaluation indices by have been used to assess the intensity of pollution in the water of Mgoua watershed. The HPI and MI indices show that this watershed is critically polluted with heavy metals. The HPI index has revealed the importance of pressure areas like station P1, which show the highest level of metals pollution. HEI and $\mathrm{C}_{\mathrm{d}}$ indices reveal a strong contamination of the water by the trace metals. Enrichment factors indicate that the study area is very highly enriched in $\mathrm{Ni}, \mathrm{Cu}, \mathrm{Cr}$ and $\mathrm{Pb}$. Enrichment is low for the other elements in relation to the geochemical background values. Industrial discharge and anthropogenic activities are the main sources of heavy metal pollution in the Mgoua watershed. It is expected that the results of this study will serve as a basis for policy makers, water resource management authorities and other stakeholders in the water and environment sector to curb heavy metal pollution in the Mgoua watershed.

\section{References}

Abdullah, E. J., 2013. Quality assessment for Shatt Al-Arab River using heavy metal pollution index and metal index. Journal of Environmental Earth Sciences. 3(5): $114-120$.

Addey, C. I., Ayoola, N. O., Omobolaji, A. A., and Tolulope, O. E., 2018. Heavy metals pollution index of surface water from Commodore channel, Lagos, Nigeria. African Journal of Environmental Science and Technology. 12(6): 191-197.

Ali, R. M., Hamad, H. A., Hussein, M. M., and Malash, G. F., 2016. Potential of using green adsorbent of heavy metal removal from aqueous solutions: adsorption kinetics, isotherm, thermodynamic, mechanism and economic analysis. Ecological Engineering. 91: 317 - 332 .

Andrews, S., and Sutherland, R. A., 2004. Cu, $\mathrm{Pb}$ and $\mathrm{Zn}$ contamination in Nuuanu watershed, Oahu, Hawaii. Science of the Total Environment. 324(1-3): 173 - 182.

Antoine, P. O., Marivaux, L., Croft, D. A., Billet, G., Ganerød, M., Jaramillo, C., and Gismondi, R. S., 2012. Middle Eocene rodents from Peruvian Amazonia reveal the pattern and timing of caviomorph origins and biogeography. Proceedings of the Royal Society B: Biological Sciences. 279(1732): 1319 - 1326.

Armstrong-Altrin, J. S., Ramos-Vázquez, M. A., Hermenegildo-Ruiz, N. Y., and Madhavaraju, J., 2021. Microtexture and $\mathrm{U}-\mathrm{Pb}$ geochronology of detrital zircon grains in the Chachalacas beach, Veracruz State, Gulf of Mexico. Geological Journal. 56(5): $2418-2438$.

Backman, B., Bodis, D., Lahermo, P., Rapant, S., and Tarvainen, T., 1997. Application of a ground water contamination index in Finland and Slovakia. Environ Geol. 36:55 - 64 .

Belmonte, Y. C., 1966. Stratigraphie du bassin sédimentaire du Cameroun. In Proceeding of the 2nd West African Micropaleontologist Colloquium, Ibadan, Nigeria. $7-23$.

Bhardwaj, B., and Kumar, P., 2017. Waste foundry sand in concrete: A review. Construction and building materials. 156: $661-674$.

Mandeng, E. P. B., Bidjeck, L. M. B., Bessa, A. Z. E., Ntomb, Y. D., Wadjou, J. W., Doumo, E. P. E., and Dieudonné, L. B., 2019. Contamination and risk assessment of heavy metals, and uranium of sediments in two watersheds in AbieteToko gold district, Southern Cameroon. Heliyon. 5(10): $25-91$.

Boateng, T. K., Opoku, F., and Akoto, O., 2019. Heavy metal contamination assessment of groundwater quality: a case study of Oti landfill site, Kumasi. Applied water science.9(2): 1 - 15 . 
Buat-Menard, P., and Chesselet, R., 1979. Variable influence of the atmospheric flux on the trace metal chemistry of oceanic suspended matter. Earth and Planetary Science Letters. 42(3): $399-411$.

Brraich, O. S., and Jangu, S., 2015. Evaluation of Water Quality Pollution Indices for Heavy Metal Contamination Monitoring in the Water of Harike Wetland (Ramsar Site), India. International Journal of Scientific and Research Publications.5(2): $1-6$.

Domingo, J. L., 1994. Metal-induced developmental toxicity in mammals: A review. Journal of Toxicology and Environmental Health, Part A Current Issues. 42(2): 123 - 141.

Dumort, J. C., 1968. Carte Géologique de reconnaissance a $1 / 500000$ avec notice explicative. Mines et Géo. du Cameroun.

Edet, A. E., and Offiong, O. E., 2002. Evaluation of Water Quality Pollution Indices for Heavy Metal Contamination Monitoring. A Study Case from Akpabuyo-Odukpani Area, Lower Cross River Basin (Southeastern Nigeria). Geo Journal. 5(4):295 - 304.

Edet, A. E., and Okereke, C. S., 2002. Delineation of shallow groundwater aquifers in the coastal plain sands of Calabar area (Southern Nigeria) using surface resistivity and hydrogeological data. Journal of African Earth Sciences. 35(3): $433-443$.

EkoaBessa, A. Z., Ngueutchoua, G., and Ndjigui, P. D., 2018a. Mineralogy and geochemistry of sediments from Simbock Lake, Yaoundé area (southern Cameroon): provenance and environmental implications. Arabian journal of geosciences. 11(22): $1-18$.

EkoaBessa, A. Z., El-Amier, Y. A., Doumo, E. P. E., and Ngueutchoua, G., 2018b. Assessment of sediments pollution by trace metals in the Moloundou swamp, southeast Cameroon. Annual Research \& Review in Biology. 1 - 13.

EkoaBessa, A. Z., Ngueutchoua, G., Janpou, A.
K., El-Amier, Y. A., Nguetnga, O. A. N. N. M., Kayou, U. R. K., and ArmstrongAltrin, J. S., 2021. Heavy metal contamination and its ecological risks in the beach sediments along the Atlantic Ocean (Limbe coastal fringes, Cameroon). Earth Systems and Environment. 5(2): 433 $-444$.

Gaillardet, J., Dupre,' B., Louvat, P., and Allegre, C. J., 1999a. Global silicate weathering of silicates estimated from large river geochemistry. Chem. Geol. (Spec. Issue Carbon Cycle 7) 159: 3-30.

Goorzadi, M., Vahabzadeh, G., Ghanbarpour, M. R., and Karbassi, A. R., 2009. Assessment of heavy metal pollution in Tilehbon River sediments, Iran. Journal of applied sciences. 9(6) : 1190 - 1193.

Hegazy, D., Abotalib, A. Z., El-Bastaweesy, M., El-Said, M. A., Melegy, A., and Garamoon, H., 2020. Geo-environmental impacts of hydrogeological setting and anthropogenic activities on water quality in the Quaternary aquifer southeast of the Nile Delta, Egypt. Journal of African Earth Sciences. 172 : 103947.

Hieng, I., 2003. Effet du remaniement par décompression de L'échantillon sur la résistance au cisaillement de l'argilesableuse jaunatre de Ndogbong dans la région de Douala au Cameroun. Journal of the Cameroon Academy of Sciences. 3(2): $107-118$.

Islam, M. S., Ahmed, M. K., Raknuzzaman, M., Habibullah-Al-Mamun, M., and Islam, M. K., 2015. Heavy metal pollution in surface water and sediment: a preliminary assessment of an urban river in a developing country. Ecological indicators. 48: $282-291$.

Jaishankar, M., Mathew, B. B., Shah, M. S., and Gowda, K. R. S., 2014. Biosorption of few heavy metal ions using agricultural wastes. Journal of Environment Pollution and Human Health. 2(1): $1-6$.

Ketchemen, B. T., 2011. Déterminants hydrogéologiques de la complexité du système aquifère du bassin sédimentaire de Douala (Cameroun) (Doctoral 
dissertation, $\mathrm{PhD}$. Thesis, University of Cheikh Anta Diop, Dakar, Senegal).

Mambenga, P. V. I., Maqsoud, A., Plante, B., Benzaazoua, M., and Ducharme, Y., 2017. Physicochemical quality of surface water: Background study prior of the Milky river sub-basin, Abitibi, Canada. WSEAS Transactions on Environment and Development. 13: 43 - 48.

Mohan, S. V., Nithila, P., and Reddy, S. J., 1996. Estimation of heavy metals in drinking water and development of heavy metal pollution index. Journal of Environmental Science \& Health Part A. 31(2): $283-289$.

Myvizhi, P., and Devi, P. A., 2020. Heavy Metal Contamination in Water of the River Cauvery-A Case Study of Erode, Salem and Namakkal Districts, Tamil Nadu.

Nasrabadi, E., 2015. Evidence of Iran's water crisis and some solutions.

Ngoupayou, J. N., Kpoumie, A., Boeglin, J. L., Liénou, G., Nfocgo, A. K., and Ekodeck, G. E., 2007. Transports solides et érosion mécanique dans un écosystème tropical d'Afrique: exemple du bassin versant de la Sanaga au Sud-Cameroun. In Proceedings of the JSIRAUF (1res Journées Scientifiques Inter-Réseaux de l'AUF).6 9.

Ndjama, J., Kamgang, K. B. V., Sigha, N. L., Ekodeck, G., and Tita, M. A., 2008. Water supply, sanitation and health risks in Douala, Cameroon. African Journal of Environmental Science and Technology. 2(12): $422-429$.

Ndondo, N. G. R., Eyong, T. E. G., Ndjama, J., Komba, D. E., Boum, N. S., Nlend, B., Makongo, M. P., Mfonka, Z., Nida, N. MJ., and Etame, J., 2021. Behavior of major ions and heavy metals risk assessment in spring and surface water on the southwest slope of Mount Cameroon (Western Africa). African Journal of Environmental Science and Technology. 15(8): $303-$ 319.

Ngueutchoua, G., Bessa, A. Z. E., Eyong, J. T., Zandjio, D. D., Djaoro, H. B., and Nfada, L. T., 2019. Geochemistry of cretaceous fine-grained siliciclastic rocks from Upper Mundeck and Logbadjeck Formations, Douala sub-basin, SW Cameroon: implications for weathering intensity, provenance, paleoclimate, redox condition, and tectonic setting. Journal of African Earth Sciences. $152: 215$ - 236.

Ngueutchoua, G., 1996. Etude des faciès et environnements sédimentaires du quaternaire supérieur du plateau continental camerounais (Doctoral dissertation, Perpignan).

Njike Ngaha, P. R., 1984. Contribution à l'étude géologique, stratigraphique et structurale de la bordure du bassin atlantique du Cameroun. These 3e cycle, Université de Yaoundé.

Noatang, D. S., Ekoa Bessa, A. Z., Brice, T. K., Ange, W. K. S., Jacques, E., and Paul, B., 2021. Heavy Metal Contamination and Ecological Risk Assessment of Overlying Water and Sediments of Nkozoa Lake (Southern Cameroon). Annual Research \& Review in Biology, 92- 109.

Olivares-Rieumont, S., De la Rosa, D., Lima, L., Graham, D. W., Katia, D., Borroto, J., and Sánchez, J., 2005. Assessment of heavy metal levels in Almendares River sediments-Havana City, Cuba. Water Research. 39(16): 3945 - 3953.

Pandey, J., and Singh, R., 2017. Heavy metals in sediments of Ganga River: up-and downstream urban influences. Applied Water Science. 7(4): 1669 - 1678.

Panigrahy, B. P., Singh, P. K., Tiwari, A. K., Kumar, B., and Kumar, A., 2015. Assessment of heavy metal pollution index for groundwater around Jharia coalfield region, India. Journal of Biodiversity and Environmental Sciences. 6(3): 33 - 39 .

Prasad, B., and Bose, J., 2001. Evaluation of the heavy metal pollution index for surface and spring water near a limestone mining area of the lower Himalayas. Environmental Geology. 41(1) : 183 188.

Regnoult, J. M., 1986. Synthèse géologique du Cameroun. Ministère des mines et de 
l'energie. 119.

Rubio, B., Nombela, M. A., and Vilas, F., 2000. Geochemistry of major and trace elements in sediments of the Ria de Vigo (NW Spain): an assessment of metal pollution. Marine pollution bulletin. 40(11): 968 980.

Sobhanardakani, S., 2016. Evaluation of the water quality pollution indices for groundwater resources of Ghahavand plain, Hamadan province, western Iran. Iranian Journal of Toxicology.10(3) : 35 40.

Surindra, M. D., Caesarendra, W., Prasetyo, T., and Mahlia, T. M. I., 2019. Comparison of the utilization of $110^{\circ} \mathrm{C}$ and $120^{\circ} \mathrm{C}$ heat sources in a geothermal energy system using organic rankine cycle (ORC) with R245fa, R123, and mixed-ratio fluids as working fluids. Processes. 7(2): 113.

Tamasi, G., and Cini, R., 2004. Heavy metals in drinking waters from Mount Amiata (Tuscany, Italy). Possible risks from arsenic for public health in the Province of Siena. Science of the total environment. 327(1-3): 41 - 51 .

Tchatchouang Chougong, D., Ngueutchoua, G., Henock Dicka, E., Ekoa Bessa, A. Z., Youbouni Ghepdeu, G. F., Bilounga, U. J. F., and Armstrong-Altrin, J. S., 2021.
Distributions of Trace Metals and Radionuclides Contamination in Alluvial Sediments from the Lobé River in Cameroon. Earth Systems and Environment. 1 - 19.

Tiwari, D. K., Dasgupta-Schubert, N., Cendejas, L. V., Villegas, J., Montoya, L. C., and García, S. B., 2014. Interfacing carbon nanotubes (CNT) with plants: enhancement of growth, water and ionic nutrient uptake in maize (Zea mays) and implications for nanoagriculture. Applied Nanoscience. 4(5): 577 - 591.

Wang, S., Cao, Z., Lan, D., Zheng, Z., and Li, G., 2008. Concentration distribution and assessment of several heavy metals in sediments of west-four Pearl River Estuary. Environmental Geology. 55:963975

WHO., 2017. World Health Organization Guidelines for drinking-water quality. Fourth edition Incorporating the first addendum. $1-631$.

Zhara, K., Sarikhani, R., Ghassemi Dehnavi, A., and Ahmadnejad, Z., 2017. Evaluation of water quality using heavy metal index and multivariate statistical analysis in Lorestan province, Iran. Journal of Advances in Environmental Health Research. 5(1): 29 $-37$.

\section{How to cite this article:}

Josephine Ndjama, GeorgeMafany, Biram Eric Belmond, Yvette Clarisse Mfopou Mewouo, Carine Tarkang, Amina Aboubakar, Opportune Léonelle Apohkeng Dongmo and Armel Zacharie Ekoa Bessa. 2021. Evaluation of Surface Water Contamination Using Heavy Metal Pollution Indices in the Mgoua Watershed, Southwestern Cameroon. Int.J.Curr.Microbiol.App.Sci. 10(11): 142-156. doi: https://doi.org/10.20546/ijcmas.2021.1011.018 